\title{
Kinetics of aerobic biodegradation of benzene and toluene in sandy aquifer material
}

\author{
Pedro J.J. Alvarez, Paul J. Anid \& Timothy M. Vogel* \\ Environmental and Water Resources Engineering, Department of Civil and Environmental Engineering, \\ The University of Michigan, Ann Arbor, MI 48109-2125, USA (* requests for offprints)
}

Received 5 March 1991; accepted 27 May 1991

Key words: benzene, biodegradation kinetics, indigenous microbes, Monod coefficients, toluene

\begin{abstract}
Monod's equation adequately described aerobic biodegradation rates of benzene and toluene by the microbial population of a sandy aquifer when these compounds were initially present at concentrations lower than $100 \mathrm{mg} / \mathrm{l}$ each. Concentrations higher than $100 \mathrm{mg} / \mathrm{l}$ were inhibitory, and no benzene or toluene degradation was observed when these compounds were initially present at $250 \mathrm{mg} / \mathrm{l}$ each. The Monod coefficients were calculated as $\mathrm{k}=8.3 \mathrm{~g}$-benzene/g-cells/day and $\mathrm{Ks}=12.2 \mathrm{mg} / \mathrm{l}$ for benzene, and $\mathrm{k}=$ $9.9 \mathrm{~g}$-toluene/g-cells/day and $\mathrm{Ks}=17.4 \mathrm{mg} / \mathrm{l}$ for toluene. Specific first-order coefficients would be $0.681 /$ $\mathrm{mg}$.day for benzene and $0.57 \mathrm{l}$.mg.day for toluene.
\end{abstract}

\section{Introduction}

Biological treatment of contaminated aquifers is receiving increasing interest. Where applicable, in situ biodegradation of the toxic petroleum hydrocarbons benzene and toluene can serve as a cost effective groundwater cleanup method (Barker et al. 1987; Hutchins et al. 1990; Lee et al. 1988; Sheehan et al. 1988; Thomas et al. 1990; Verheul et al. 1988; Werner 1985). Assessing the biodegradation kinetics of these compounds is essential in predicting the extent to which contamination will spread and in estimating the duration of in situ biodegradation cleanup operations.

Monod kinetics are widely used to describe biodegradation rates of organic contaminants in aquifer systems (Borden \& Bedient 1986; MacQuarrie et al. 1990; Molz et al. 1986; Widdowson et al. 1988). Much of the versatility of Monod's equation is due to the fact that it can describe biodegradation rates following zero- to first-order kinetics with respect to the target substrate concentration. However, Monod's equation cannot account for substrate inhibition and may be inappropriate to describe biodegradation kinetics of benzene and toluene when these contaminants are present at elevated concentrations.

Monod's equation is empirical, and the two coefficients that describe the equation are system specific. Therefore, caution should be exercised in extrapolating coefficients measured in one environment to another. Several kinetic studies with pure cultures or with mixed cultures using sludge from biological reactors have measured Monod coefficients for benzene and toluene (Table 1). However, reported values of Monod coefficients for benzene and toluene degradation in aquifer material are virtually nonexistent. Barker et al. (1987) reported zero-order maximum degradation rates for benzene in aquifer material. However, the microbial concentration was not reported, and the maximum specific substrate utilization rate $(k)$ 
could not be calculated. The half-saturation coefficient (Ks) was not determined in their study. MacQuarry et al. (1990) estimated Monod coefficients for toluene degradation in aquifer material. However, these coefficients were not directly measured using a wide range of toluene concentrations. Rather, these coefficients were obtained by fitting a contaminant transport-biodegradation model to data from flow-through columns. A few first-order kinetic coefficients for benzene and toluene degradation in aquifer systems have been reported (Table 2). However, these coefficients often correspond to natural attenuation limited by the availability of essential nutrients (e.g. oxygen), and may not apply to enhanced biorestoration conditions.

The objectives of this study were to establish whether Monod's equation adequately describes the kinetics of benzene and toluene aerobic degradation by the indigenous microbial population of a sandy aquifer; to determine at what substrate concentrations is this equation appropriate; and to measure the corresponding Monod coefficients under enhanced biorestoration conditions.

\section{Theoretical background}

The hyperbolic equation proposed by Monod (1949) to describe the growth of bacterial cultures as a function of a limiting nutrient concentration was modified by Lawrence \& McCarty (1970) to describe the effect of substrate concentration on the rate at which microorganisms remove a limiting substrate:

$$
-\frac{\partial S}{\partial t}=\frac{k S X}{K s+S}
$$

where

$$
\begin{aligned}
\mathrm{S}= & \text { Substrate concentration (mg-substrate/l) } \\
\frac{-\partial \mathrm{S}}{\partial \mathrm{t}}= & \begin{array}{l}
\text { Substrate utilization rate } \\
\text { (mg-substrate/l.day) }
\end{array} \\
\mathrm{X}= & \text { Microbial concentration (mg-cells/l) } \\
\mathrm{k}= & \text { Maximum specific substrate utilization } \\
& \text { rate (g-substrate/g-cells/day); and } \\
\mathrm{Ks}= & \begin{array}{l}
\text { Half-saturation coefficient } \\
\text { (mg-substrate/l) }
\end{array}
\end{aligned}
$$

The intrinsic coefficients $\mathbf{k}$ and Ks characterize Monod's equation. These coefficients can be determined by using non-linear regression as well as by several different techniques that transform Monod's equation into a linear form. Among these techniques, the Hanes linearization was selected in this study because of its simplicity, adequacy of data spread, and validity of the use of a least-square fit (Dowd \& Riggs 1965; Grady \& Lim 1980). This technique linearizes Monod's equation by a double inversion followed by multiplication by $\mathrm{S}$ to obtain:

$$
\frac{S X}{-\frac{\partial S}{\partial t}}=\frac{K s}{k}+\frac{S}{k}
$$

If Monod's equation fits the data adequately, a plot of the substrate concentration divided by the specific substrate utilization rate $S / \partial S / \partial t / X)$ versus substrate concentration ( $S$ ) results in a straight line, giving $\mathrm{k}$ as the inverse of the slope and $\mathrm{Ks}$ as quotient between the intercept and the slope.

\section{Experimental methodology}

\section{Experimental design}

Benzene and toluene were added concurrently to batch incubations seeded with aquifer material to obtain the following approximate aqueous concentrations of each compound: $1,10,50,100$ and $250 \mathrm{mg} / \mathrm{l}$. Removal rates were measured over this wide range of concentrations in order to cover the transition from zero- to first-order kinetics with respect to substrate concentration. Batches were duplicated and each batch yielded a value for

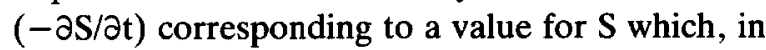
turn, yielded a point in the Hanes plot. Initial removal rates were used in this analysis in order to preclude confounding effects arising from increases in biomass. Initial rates were measured at the onset of biodegradation, which followed an acclimation period of 1 to 2 days during which the microbial concentration remained relatively constant. Microbial numbers were determined at the onset of biodegradation and were assumed to remain constant over the initial rate measurement. 
Each batch had a negative (sterile) control which was used to correct for benzene and toluene disappearance due to abiotic losses such as adsorption and volatization. Therefore, the measurements of $-\partial \mathrm{S} / \partial \mathrm{t}$ reflect removal due to biodegradation alone.

\section{Media}

Basal mineral medium was prepared to provide essential inorganic nutrients and vitamins for microbial metabolism. The medium contained the following (in mg per liter of Milli-Q water): $\mathrm{NH}_{4} \mathrm{Cl}$ (100); $\mathrm{KH}_{2} \mathrm{PO}_{4}(700) ; \mathrm{K}_{2} \mathrm{HPO}_{4}(1,000) ; \mathrm{NaCl}(10) ;$ $\mathrm{CaCl}_{2}$ (5); $\mathrm{MgCl}_{2}$ (10); $\mathrm{CuCl}_{2} \cdot 2 \mathrm{H}_{2} \mathrm{O}$ (0.0392);

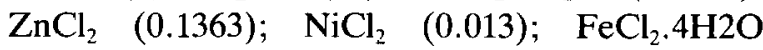

Table 1. Monod coefficients for aerobic blodegradation of benzene and toluene.

\begin{tabular}{lllllll}
\hline Compound & $\mathrm{k}$ & $\mathrm{Ks}$ & $\mathrm{Y}$ & Specific & Method of measurement & References \\
& $\begin{array}{ll}\text { (g-compound } \\
\text { per g-cells }\end{array}$ & & g-compound) & first-order & \\
& coefficient & \\
per day) & & & $(\mathrm{k} / \mathrm{Ks})$ & \\
& & & $(\mathrm{l} / \mathrm{mg} . \mathrm{d})$ &
\end{tabular}

\begin{tabular}{|c|c|c|c|c|c|c|}
\hline Benzene & 4.7 & 10.8 & 0.39 & 1.33 & $\begin{array}{l}\text { Respirometry, mixed } \\
\text { culture suspension }\end{array}$ & Grady et al. (1989) \\
\hline Benzene & $0.033 \mathrm{mg} / 1 . \mathrm{d}^{d}$ & - & - & - & $\begin{array}{l}\text { Substrate disappearance } \\
\text { in aquifer microcosms }\end{array}$ & Barker et al. (1987) \\
\hline Toluene & 2.97 & - & 1.42 & - & $\begin{array}{l}\text { Chemostats, Pseudomonas } \\
\text { putida } \text { suspension }\end{array}$ & Vetch et al. (1988) \\
\hline Toluene & - & - & - & 12 & $\begin{array}{l}\text { Total }{ }^{14} \mathrm{C} \text {-labeled product } \\
\text { production, suspension of } \\
\text { Pseudomonas putida sp. T2 }\end{array}$ & Button (1985) \\
\hline Toluene & 0.004 & 0.33 & 0.01 & 0.01 & $\begin{array}{l}\text { Total }{ }^{14} \text { C-labeled product } \\
\text { production, suspension of } \\
\text { Pseudomonas sp. T2 } \\
\text { (marine strain) } \\
\text { Uninduced cells }\end{array}$ & Button (1985) \\
\hline Toluene & 11 & 0.43 & 0.28 & 25.5 & $\begin{array}{l}\text { Total }{ }^{14} \text { C-labeled product } \\
\text { production, suspension of } \\
\text { Pseudomonas sp. T2 } \\
\text { (marine strain) } \\
\text { Induced cells }\end{array}$ & Button (1985) \\
\hline Toluene & 0.013 & 0.034 & 0.1 & 0.38 & $\begin{array}{l}{ }^{14} \mathrm{CO}_{2} \text { production, } \\
\text { Pseudomonas } \mathrm{sp} . \mathrm{T} 2 \\
\text { (marine strain) } \\
\text { Uninduced cells }\end{array}$ & Robertson \& Button (1987) \\
\hline Toluene & 0.33 & 0.044 & 0.1 & 7.7 & $\begin{array}{l}{ }^{14} \mathrm{CO}_{2} \text { production, } \\
\text { Pseudomonas sp. } \mathrm{T} 2 \\
\text { (marine strain) } \\
\text { Induced cells }\end{array}$ & Robertson \& Button (1987) \\
\hline Toluene & 0.49 & 0.65 & 0.43 & 0.75 & $\begin{array}{l}\text { Computer model fit to } \\
\text { data from flow through } \\
\text { column packed with } \\
\text { aquifer material }\end{array}$ & MacQuarry et al. (1990) \\
\hline Toluene & 4.32 & 0.15 & - & 28.8 & $\begin{array}{l}\text { Substrate disappearance } \\
\text { in batch incubations with } \\
\text { denitrifying sewage sludge }\end{array}$ & Jørgensen et al. (1990) \\
\hline
\end{tabular}

\footnotetext{
${ }^{a}$ Reported as zero-order maximum rate $=\mathrm{k} \mathrm{X}$ with inttial benzene concentration of $2 \mathrm{mg} / \mathrm{l}$. Microbial concentration, $\mathrm{X}$, not reported.
} 
(0.7016); $\mathrm{AlCl}_{3}$ (0.1106); $\mathrm{MnCl}_{2} .4 \mathrm{H}_{2} \mathrm{O}$ (0.2807); $\mathrm{CoCl}_{2} .6 \mathrm{H}_{2} \mathrm{O}(0.0382) ; \mathrm{Na}_{2} \mathrm{MoO}_{4} \cdot 2 \mathrm{H}_{2} \mathrm{O}(0.0254)$; $\mathrm{H}_{3} \mathrm{BO}_{3}$ (0.0382); $\mathrm{Na}_{2} \mathrm{SO}_{4}(0.1420)$; biotin (0.02); folic acid (0.02); pyridoxine $\mathrm{HCl}(0.1)$; riboflavin (0.05); thiamin (0.05); nicotinic acid (0.05); pantothenic acid (0.05); vitamin B-12 (0.001); and $p$ aminobenzoic acid (0.05). All mineral medium chemicals as well as sodium azide were obtained from Fisher Scientific (Fairlawn, NJ). Benzene was obtained from EM Science (Cherry Hill, NJ). Toluene was obtained from J.T. Baker (Phillipsburg, NJ).

\section{Batch incubations}

Sandy aquifer material of low organic carbon content $(<0.1 \%$ ) (Chiang et al. 1989) was used to seed the batches. This aquifer material contained no detectable levels of benzene, toluene, or xylene (BTX), although the aquifer underlies a gas plant facility in Northern Michigan and was previously contaminated at an overall level of approximately $200 \mu \mathrm{g} / \mathrm{L}$ total BTX (Kukor \& Olsen 1989). Batches were prepared by adding 16 grams of drained aquifer material (i.e. $10 \mathrm{ml}$ bulk volume) and $50 \mathrm{ml}$ of mineral medium to $120 \mathrm{ml}$ serum bottles. Aerobic conditions were maintained in the batches by a $60 \mathrm{ml}$ headspace volume containing air. Benzene and toluene were injected as pure stock with a 10- $\mu$ l syringe \# 701 (Hamilton Co., Reno, NV). Oxygen gas (10 ml at $1 \mathrm{~atm})$ was also injected into the headspace in order to ensure an oxygen supply in excess of the stoichiometric requirements for mineralization of benzene and toluene. The batches were sealed with Teflon-lined caps and stored inverted at $25^{\circ} \mathrm{C}$ in the dark and shaken on an orbital shaker at $100 \mathrm{rpm}$. Sterile controls were prepared by duplicating the batches and autoclaving them for $30 \mathrm{~min}$ at $120^{\circ} \mathrm{C}$. Sodium azide $(2000 \mathrm{mg} / \mathrm{l})$ was added to the controls to aid in inhibiting potential microbial activity due to microbial contamination of the controls during sampling.

\section{Analytical procedure}

A $500 \mu \mathrm{l}$ gastight syringe \# 1750 (Hamilton Co., Reno, NV) equipped with a thin (30-gage) disposable needle (Becton Dickinson \& Co., Rutherford, $\mathrm{NJ}$ ) was used to withdraw aqueous samples $(0.5 \mathrm{ml})$ from each batch. Samples were taken approximately every four hours, transferred to $5 \mathrm{ml}$ vials, and capped with Teflon-coated septa prior to automated headspace analysis.

Benzene and toluene were analyzed in a Hewlett Packard 5890 gas chromatograph (GC) equipped

Table 2. First-order coefficients for biodegradation of benzene and toluene.

\begin{tabular}{|c|c|c|c|c|c|c|}
\hline Compound & $\begin{array}{l}\mathrm{K}^{\prime} \\
\left(\mathrm{day}^{-1}\right)\end{array}$ & $\begin{array}{l}\text { Half-life } \\
\text { (days) }\end{array}$ & $\begin{array}{l}X \\
(\mathrm{mg} / \mathrm{l})\end{array}$ & $\begin{array}{l}\text { Specific } \\
\text { first-order } \\
\text { coefficient } \\
\left(K^{\prime} / X\right)(1 / m g . d)\end{array}$ & Method of measurement & References \\
\hline Benzene & 662 & 0.001 & 2,500 & 0.27 & $\begin{array}{l}\text { Substrate disappearance } \\
\text { in batch incubations with } \\
\text { activated sludge mixed-liquor }\end{array}$ & Jones (1984) \\
\hline Benzene & 0.006 & 110 & - & - & $\begin{array}{l}\text { Substrate disappearance } \\
\text { in landfill leachate }\end{array}$ & Zoetman et al. (1981) \\
\hline Toluene & 626 & 0.0011 & 2,500 & 0.25 & $\begin{array}{l}\text { Substrate disappearance } \\
\text { in batch incubations with } \\
\text { activated sludge mixed-liquor }\end{array}$ & Jones (1984) \\
\hline Toluene & 0.019 & 36 & - & - & $\begin{array}{l}\text { Substrate disappearance } \\
\text { in landfill leachate }\end{array}$ & Zoetman et al. (1981) \\
\hline $\begin{array}{l}\text { Total Benzene, } \\
\text { Toluene and } \\
\text { Xylene }\end{array}$ & 0.01 & 70 & - & - & $\begin{array}{l}\text { Substrate disappearance } \\
\text { in sandy aquifer, limited } \\
\text { by oxygen avalability }\end{array}$ & Chiang et al. (1989) \\
\hline
\end{tabular}


with a HP 19395A automatic headspace sampler and a flame ionization detector (FID) connected to a HP 300 computer that used HPGC ChemStation software to integrate the signal. The 30-m HP-5 capillary column (crosslinked 5\% Ph Me Silicone) had an inner diameter of $0.5 \mathrm{~mm}$ and a film thickness of $2.5 \mu \mathrm{m}$. A relative standard deviation of $\pm 5 \%$, including inconsistencies in sample collection, was obtained for both benzene and toluene measurements. The limit of detection of this procedure was approximately $0.01 \mathrm{mg} / \mathrm{l}$.

A biological oxygen monitor YSI 530, equipped with a microchamber and an oxygen micro probe (YSI Inc., Yellow Springs, $\mathrm{OH}$ ) was used to measure dissolved oxygen in samples withdrawn from the batches in order to ensure that aerobic conditions prevailed.

Microbial numbers were measured with the Acridine Orange Direct Count (AODC) Procedure (Webster et al. 1985). Both attached and suspended microbes were counted, and the total microbial concentration was used in the analysis. A cell wet weight of $10^{-9} \mathrm{mg}$ was assumed to convert cell numbers to biomass. This cell weight is based on a typically observed cell size of $1 \mu \mathrm{m}^{3}$ and a microbial density similar to that of water (i.e. $1.04 \mathrm{~g} / \mathrm{cm}^{3}$ ).

\section{Results}

Microbial numbers did not increase significantly from the initial count prior to addition of benzene and toluene to the time when the onset of biodegradation was observed. Typically, cell counts in the order of $10^{6}$ per gram of aquifer material were observed. Using a bulk density of $1.6 \mathrm{~g} / \mathrm{cm}^{3}$ for the aquifer material, a microbial concentration $(\mathrm{X})$ of approximately $1.6 \mathrm{mg} / \mathrm{l}$ was calculated.

Each batch was used to obtain an initial specific substrate utilization rate measurement (i.e. the measured degradation rate divided by the microbial concentration of $1.6 \mathrm{mg} / \mathrm{l}$ ) corresponding to an initial substrate concentration which, in turn, yielded a point in the Hanes linearization. Data from the batches with initial benzene and toluene concentration of $250 \mathrm{mg} / \mathrm{l}$ (each) were not included in the estimation of Monod coefficients because benzene

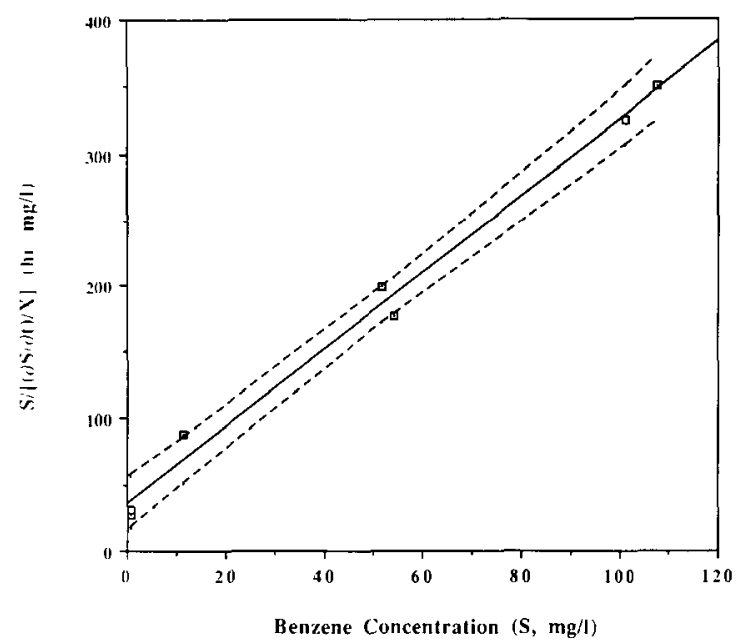

Fig. 1. Hanes linearization for benzene. Observed ratio of initial benzene concentration to specific benzene utilization rate ( $\square$; least square regression line (-); 95\% confidence envelope $(---)$.

or toluene were not degraded in these batches for over a one-month period. Abiotic losses of benzene and toluene, assessed on appropriate sterile controls, were negligible over the initial-rate measurement period ( $<1 \%$ lost). The Hanes plots for benzene (Fig. 1) and toluene (Fig. 2) degradation yielded the following linear regressions:

Benzene: $\mathrm{y}=35.322+2.8967 \mathrm{x} ; \mathrm{r}^{2}=0.991$ with a $95 \%$ confidence interval for intercept $=[15.34$, $55.31 \mathrm{~h} \mathrm{mg} / \mathrm{l}]$ and $95 \%$ confidence interval for slope $=[2.58,3.22 \mathrm{~h}]$. Therefore, $\mathrm{k}=1 /$ slope $=$ $8.3 \mathrm{~g}$-benzene/g-cells/day, and $\mathrm{Ks}=$ intercept/ slope $=12.2 \mathrm{mg}$-benzene $/ \mathrm{l}$. The specific first-order coefficient would be $\mathrm{k} / \mathrm{Ks}=0.68 \mathrm{l} / \mathrm{mg} /$ day.

Toluene: $\mathrm{y}=42.204+2.4236 \mathrm{x} ; \mathrm{r}^{2}=0.957$ with a $95 \%$ confidence interval for intercept $[5.94,78.46 \mathrm{~h}$ $\mathrm{mg} / \mathrm{ll}$ and a $95 \%$ confidence interval for slope $=$ $[1.71,3.14 \mathrm{~h}]$. Therefore, $\mathrm{k}=1 / \mathrm{slope}=9.9 \mathrm{~g}$-toluene/g-cells/day, and $\mathrm{Ks}=$ intercept/slope $=$ $17.4 \mathrm{mg}$-toluene/l. The specific first-order coefficient would be $\mathrm{k} / \mathrm{Ks}=0.57 \mathrm{l} / \mathrm{mg} /$ day. 


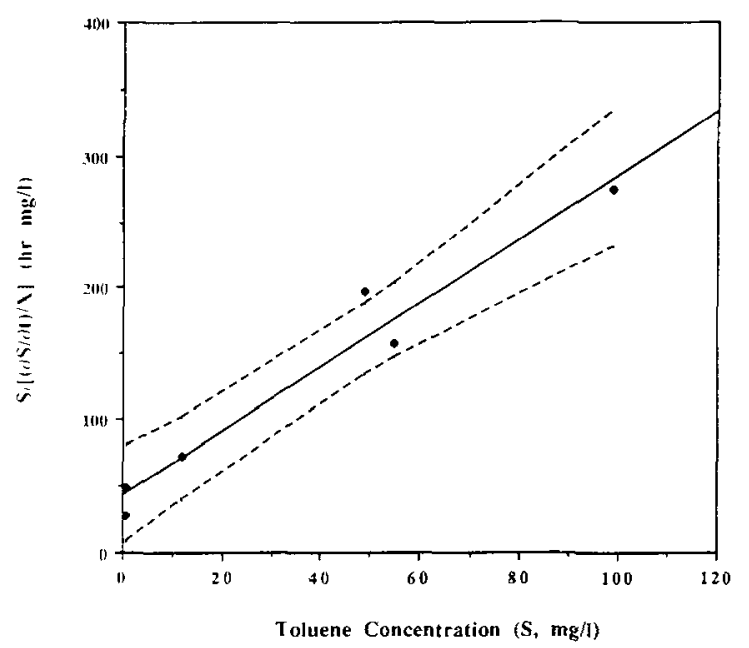

Fig. 2. Hanes linearization for toluene. Observed ratio of initial toluene concentration to specific toluene utilization rate $(\Delta)$; least square regression line (-); $(-5 \%$ confidence envelope $(---)$.

\section{Discussion}

Monod's equation described adequately the biodegradation kinetics of benzene and toluene at concentrations lower than $100 \mathrm{mg} / \mathrm{l}$. This is substantiated by the high correlation coefficients $\left(r^{2}\right)$ obtained by the Hanes linearizations $(0.991$ for benzene and 0.957 for toluene). However, the correlation of a linearization technique is in itself insufficient evidence for proof of adequate Monod fit. The calculated Monod coefficients were used to compare simulated versus observed specific substrate utilization rates as a function of substrate concentration for benzene (Fig. 3) and toluene (Fig. 4), and the good fit of Monod's equation to the kinetics data was established (note: a similar good fit was not obtained with a Lineweaver-Burk linearization).

No degradation was observed in batches with initial benzene and toluene concentrations of $250 \mathrm{mg} / \mathrm{l}$. One cannot exclude the possibility that these compounds exerted toxicity at these relatively high concentrations. This explanation for the lack of benzene and toluene degradation is consistent with reports of benzene inhibiting the microbial population of industrial wastewater treatment units when present in concentrations higher than

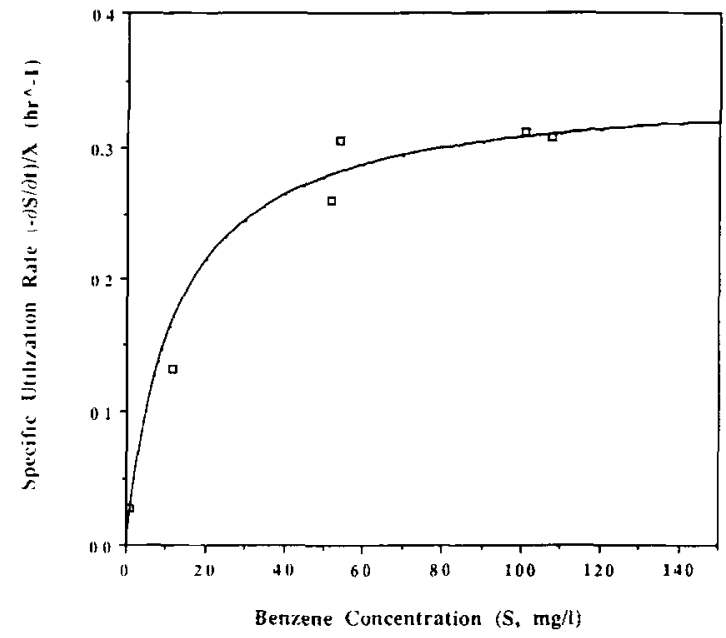

Fig. 3. Biodegradation kinetics of benzene in sandy aquifer material. Observed specific benzene utilization rate ( $\square$; Monod's equation fit with $\mathrm{k}=0.345 \mathrm{hr}^{-1}\left(8.3\right.$ day $\left.^{-1}\right)$ and $\mathrm{Ks}=$ $12.2 \mathrm{mg} / \mathrm{l}(\longrightarrow)$.

$100 \mathrm{mg} / \mathrm{l}$ (Davis et al. 1981). However, this threshold for substrate inhibition for benzene and toluene is not universally applicable. The threshold for substrate inhibition is much lower for oligotrophs. For instance, low toluene concentrations $(1 \mathrm{mg} / \mathrm{l})$ have been reported to inhibit toluene-degrading bacte-

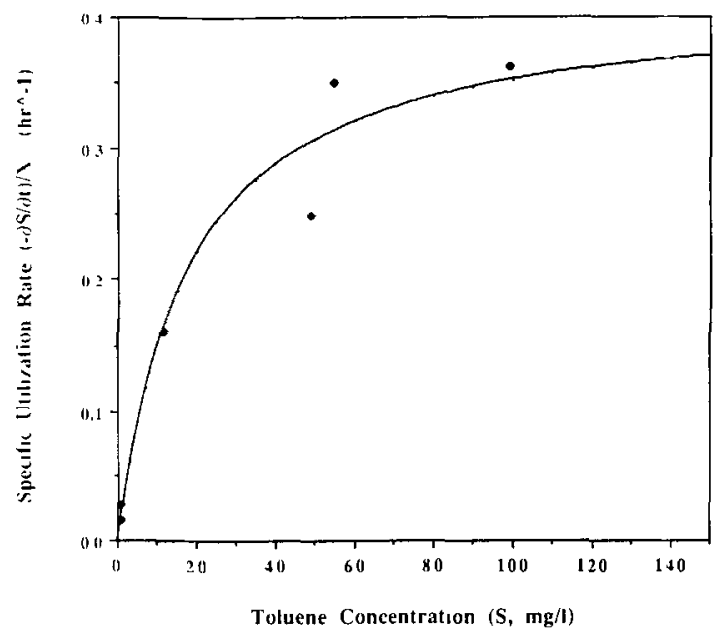

Fig. 4. Biodegradation kinetics of toluene in sandy aquifer material. Observed specific toluene utilization rate $(\bullet)$; Monod's equation fit with $\mathrm{k}=0.413 \mathrm{hr}^{-1}\left(9.9 \mathrm{day}^{-1}\right)$ and $\mathrm{Ks}=$ $17.4 \mathrm{mg} / \mathrm{l}(\longrightarrow)$. 
ria isolated from an oligotrophic marine environment (Button \& Robertson 1986).

Monod's equation does not incorporate substrate toxicity effects, and therefore overestimates biodegradation rates at substrate concentrations sufficiently high to hinder microbial activity (e.g. $250 \mathrm{mg} / \mathrm{l}$ ). This limitation of Monod's equation is not significant for the purpose of estimating biodegradation rates of benzene and toluene in contaminated aquifers because these compounds are rarely found at such elevated concentrations. In other words, benzene and toluene contamination usually occurs as a result of inadvertent release of petroleum byproducts such as fuel. If the chemical system follows Raoult's law, the expected concentration of an individual hydrocarbon in water that is in equilibrium with fuel can be estimated by multiplying its water solubility by its mole fraction in the fuel (Wilson et al. 1990). Regular gasoline contains a molar fraction of 0.0093 benzene (water solubility $1750 \mathrm{mg} / \mathrm{l}$ ) and 0.0568 toluene (water solubility $535 \mathrm{mg} / \mathrm{l}$ ) (Johnson et al. 1990). Consequently, the expected concentrations of benzene and toluene in water in equilibrium with gasoline are, respectively, 16 and $30 \mathrm{mg} / \mathrm{l}$. These concentrations are within the range where Monod's equation proved adequate. However, in the event of a spill of pure benzene or toluene, the concentration of these compounds would approach their solubility in water in the vicinity of the contamination source. In such cases, a kinetics expression that incorporates substrate inhibition (e.g. Haldane's equation) should be employed to estimate biodegradation rates.

The confidence intervals of the Hanes linearizations (see results) reflect that the intercept is subject to more relative variation than the slope. Since $\mathbf{k}$ is estimated from the slope alone and $\mathrm{Ks}$ is calculated as the quotient of the intercept and the slope, it follows that our estimates of $k$ are more reliable than our estimates of Ks.

There is considerable variation among the relatively few published values of Monod coefficients for benzene and toluene (Table 1). This apparent discrepancy reflects the fact that Monod's equation is empirical and Monod coefficients are system specific. The catabolic diversity of microbes capable of degrading benzene and toluene is an important factor in accounting for the variation of Monod coefficients. For instance, Monod coefficients reported by Button (1985) and Robertson \& Button (1987) are considerably smaller than the values estimated in this study. However, our experiment was conducted with mixed cultures under nutrientrich conditions which probably selected for the growth of eutrophs while their experiments were performed with much lower toluene concentrations using pseudomonad pure cultures isolated from an oligotrophic (marine) environment. Oligotrophs tend to exhibit smaller $\mathbf{k}$ and $\mathrm{Ks}$ values than eutrophs in order to adapt to nutrient-limiting conditions (Slater \& Lovatt 1984).

Regardless of the catabolic diversity of microbes, a given microbial population is likely to exhibit different biodegradation kinetics in different systems. For instance, Ks values for a given compound have been reported to be orders of magnitude larger in soils than in aquatic systems (Alexander \& Scow 1989; Tiedje 1987). Apparently, there is a lower degree of contact in soil between the substrate and the microbes which inflates the apparent $\mathrm{Ks}$ value. The aquifer material used in this study had a very low organic content $(<0.1 \%)$ and bioavailability of benzene and toluene was not significantly affected by adsorption of these compounds to the aquifer material. However, aquifer materials of high organic content may exhibit significant sorption of benzene and toluene, which could in turn hinder the bioavailability of these compounds and result in larger values of Ks. Other environmental factors such as temperature, $\mathrm{pH}$ and availability of inorganic nutrients will also affect the kinetics of biodegradation.

The concentration of benzene and toluene found in contaminated aquifers is often substantially lower than our estimated $\mathrm{Ks}$ values (12.2-17.4 mg/l of benzene and toluene, respectively). In this case, Monod's equation reduces to a first-order expression with a specific first-order coefficient equal to $\mathrm{k} / \mathrm{Ks}$, which is numerically equal to the overall first-order coefficient $\left(K^{\prime}\right)$ divided by the microbial concentration $(\mathrm{X})$. The measured specific first-order coefficients $(0.68$ and $0.57 \mathrm{l} / \mathrm{mg}$.day for benzene and toluene, respectively) indicate that ben- 
zene and toluene half-lives in the order of one day may be expected when adequate environmental conditions exist in contaminated aquifers.

Published first-order coefficients for benzene and toluene degradation $\left(K^{\prime}\right)$ differ by orders of magnitude (Table 2). However, specific first-order coefficients $\left(K^{\prime} / X\right)$ do not vary as much, typically ranging from 0.1 to $1.01 / \mathrm{mg}$.day (Table 1 and Table $2)$. This might indicate the importance in measuring the concentration of microorganisms for kinetic coefficients determinations.

The estimation of microbial numbers is a major source of variation in the determination of specific first-order coefficients and specific substrate utilization rates. Direct counting methods, such as the AODC procedure used in this study, are more reliable than viable plate counts for determining the total number of aquifer microorganisms. Alexander (1977) has reported that, at best, artificial media are capable of detecting only 1 to $10 \%$ of the total number of soil microorganisms. Shimp \& Pfaender (1985) have also reported AODC results to be an order of magnitude larger than enumerations by plate counts. A new procedure that can differentiate between benzene and toluene degraders and other microbes growing on benzene and toluene metabolites or other substrates (e.g. dead cells or humic material) would improve measurements of microbial kinetic constants.

\section{Conclusions}

Monod's Equation adequately described biodegradation rates of benzene and toluene by the microbial population of a sandy aquifer. However, aqueous concentrations of benzene and toluene higher than $100 \mathrm{mg} / \mathrm{l}$ were inhibitory and the use of Monod's equation is inappropriate at such elevated concentrations. Monod coefficients are system-specific, and caution should be exercised in extrapolating values measured in a given environment to another. Factors that contribute to the wide variability of reported coefficients include the catabolic diversity of microbes, variations in environmental conditions, and the different experimental and analytical procedures used in their determination.

\section{Acknowledgements}

This work was supported in part by the Michigan Oil and Gas Association (DRDA number 901112), the NIEHS Superfund Research Center (Grant \# 5 P42 ES04911-03), and the Office of Research and Development, U.S. Environmental Protection Agency under Grant R815750 to the Great Lakes and Mid-Atlantic Hazardous Substance Research Center. Partial funding of the research activities of the Center is also provided by the State of Michigan Department of Natural Resources. The content of this publication does not necessarily represent the views of any agency.

\section{References}

Alexander M (1977) Introduction to Soil Microbiology, 2nd edition. John Wiley \& Sons, NY

Alexander M \& Scow KM (1989) Kinetics of Biodegradation in Soil. In: Shawney BL \& Browns K (Eds) Reactions and Movement of Organic Chemicals in Soils. Soil Science Society of America 22: 243-269

Barker JF, Patrick GC \& Major D (1987) Natural Attenuation of Aromatic Hydrocarbons in a Shallow Sand Aquifer. Groundwater Monitoring Review (Winter): 64-71

'Borden RC \& Bedient PB (1986) Transport of Dissolved Hydrocarbons Influenced by Oxygen-Limited Biodegradation 1 . Theoretical Development. Water Resources Research 22: 1973-1982

Button DK (1985) Kinetics of Nutrient-Limited Transport and Microbial Growth. Microbiological Reviews 49: 270-297

Button DK \& Robertson BR (1986) Dissolved Hydrocarbon Metabolism: The Concentration-Dependent Kinetics of Toluene Oxidation in Some North American Estuaries. Limnol. Oceanogr. 31: 101-111

Chiang CY, Salanitro JP, Chai EY, Colthart JD \& Klein CL (1989) Aerobic Biodegradation of Benzene, Toluene, and Xylene in a Sandy Aquifer - Data Analysis and Computer Modeling. Groundwater 27: 823-834

Davis E, Murray HE, Liehr JG \& Powers EL (1981) Basic Microbial Degradation Rates and Chemical Byproducts of Selected Organic Compounds. Water Research 15: 1125-1127

Dowd JE \& Riggs DS (1965) A Comparison of Estimates of Michaelis-Menten Kinetic Constants from Various Linear Transformations. The Journal of Biological Chemistry 240: 863-869

Grady CP \& Lim HC (1980) Biological Wastewater TreatmentTheory and Applications. Marcel Dekker, Inc. New York, NY

Grady CP, Aichinger G, Cooper SF \& Naziruddin M (1989) 
Biodegradation Kinetics for Selected Toxic/Hazardous Compounds. Proceedings of the 1989 A \&WMA/EPA International Symposium on Hazardous Waste Treatment: Biosystems for Pollution Control. Cincinnati, OH (February 1989): 141153

Harvey RW, Smith RL \& George L (1984) Effect of Organic Contamination upon Microbial Distributions and Heterotrophic Uptake in Cape Cod, Mass., Aquifer. Appl. Environ. Microbiol. 48: 1197-1202

Hutchins SR, Wilson JT, Douglas RH \& Hendrix DJ (1990) Field and Laboratory Evaluation of the Use of Nitrate to Remove BTX from a Fuel Spill. Proceedings: Environmental Research Conference on Groundwater Quality and Waste Disposal. Washington D.C. May 2-4, 1989. Edited by I.P. Muraka, Electric Power Research Institute, Palo Alto, CA. and S. Cordle, U.S. Environmental Protection Agency. Washington, DC (pp 29-1-29-17)

Johnson PC, Kemblowski MW \& Colthart JD (1990) Quantitative Analysis for the Cleanup of Hydrocarbon-Contaminated Soils by In-Situ Soil Venting. Groundwater 28: 413-429

Jones BE (1984) Fate of Toxic Organic Compounds in Activated Sludge and Integrated Activated Sludge/Carbon Treatment Systems. Ph.D. thesis, Environmental and Water Resources Engineering, Department of Civil Engineering. The University of Michigan, Ann Arbor

Jørgensen C, Flyvberg J, Jensen BK, Arvin E, Olsen SK \& Mortensen E (1990) Toluene Metabolism and its effects on $o$-Cresol Transformation under Nitrate Reducing Conditions. COST Seminar on Anaerobic Biodegradation of Xenobiotic Compounds, Copenhagen, November 1990

Kukor JJ \& Olsen RH (1989) Diversity of Toluene Degradation Following Long Term Exposure to BTEX in situ. In: Kamely D, Chakabarty A \& Omenn G (Eds) Biotechnology and Biodegradation - 1989 (pp 5-21)

Lawrence A \& McCarty PL (1970) Unified Basis for Biological Treatment Design and Operation. Journal of the Sanitary Engineering Division. ASCE 96: 757-778

Lee MD, Thomas JM, Borden RC, Bedient PB, Ward CH \& Wilson JT (1988) Biorestoration of aquifers contaminated with organic compounds. CRC Critical Reviews in Environmental Control. 1: 29-89

MacQuarrie KTB, Sudicky EA \& Frind EO (1990) Simulation of Biodegradable Organic Contaminants in Groundwater 1. Numerical Formulation in Principal Directions. Water Resources Research 26: 207-222

Molz F, Widdowson J, Benefield MA et al. (1986) Simulation of Microbial Growth Dynamics Coupled to Nutrient and Oxygen Transport in Porous Media, Water Resour. Res. 22: 1207-1216

Monod J (1949) The Growth of Bacterial Cultures. Annual Review of Microbiology 3: 371-394

Robertson BR \& Button DK (1987) Toluene Induction and Uptake Kinetics and Their Inclusion in the Specific-Affinity
Relationships Describing Rates of Hydrocarbon Metabolism. Appl. Environ. Microbiol. 53: 2193-2205

Sheehan PJ, Schneiter RW, Mohr TKG \& Gersberg RM (1988) Bioreclamation of Gasoline Contamination Without Oxygen Addition. In: Proceedings of the Second National Outdoor Action Conference on Aquifer Restoration, Groundwater Monitoring, and Geophysical Methods, Vol 1. NWWA, Las Vegas, Nevada, May 23-26, 1988 (pp 183-199)

Shimp R \& Pfaender F (1985) Influence of Easily Degradable Naturally Occurring Carbon Substrates on Biodegradation of Monosubstituted Phenols by Aquatic Bacteria. Appl. Environ. Microbiol. 49: 394-401

Slater JH \& Lovatt D (1984) Biodegradation and the Significance of Microbial Communities. In: Gibson DT (Ed) Microbial Degradation of Organic Pollutants (pp 439-485). Marcel Dekker, Inc. NY

Thomas JM, Gordy VR, Fiorenza S \& Ward CH (1990) Biodegradation of BTEX in Subsurface Materials Contaminated with Gasoline: Granger, Indiana. Water Sci. Tech. 6: 53-62

Tiedje JM (1987) Ecology of Denitrification and Dissimilatory Nitrate Reduction to Ammonium. In: Zehnder AJB (Ed) Environmental Microbiology of Anaerobes (pp 179-244). John Wiley \& Sons. NY

Verheul JHAM, van den Berg R \& Eikelboom DH (1988) In situ Biorestoration of a Subsoil Contaminated with Gasoline. In: Wolf $\mathrm{K}$, van den Brink WJ \& Colon FJ (Eds) Contaminated Soil '88 (pp 705-716). Kluwer Academic Publishers

Vecht SE, Platt MW, Er-El Z \& Goldberg I (1988) The growth of Pseudomonas putida on $m$-Toluic Acid and toluene in batch and in Chemostat Cultures. Appl. Microbiol. Biotechnol. 27: 587-592

Webster JJ, Hampton GJ, Wilson JT, Ghiorse WC \& Leach FR (1985) Determination of Cell Numbers in Subsurface Samples. Groundwater 23: 17-23

Werner P (1985) A New Way for the Decontamination of Polluted Aquifers by Biodegradation. Water Supply 3: 41-47

Widdowson MA, Molz FJ \& Benefield LD (1988) A numerical Transport Model for Oxygen- and Nitrate-Based Respiration Linked to Substrate and Nutrient Availability in Porous Media. Water Resour. Res. 24: 1553-1565

Wilson J, Leach L, Michalowski J, Vandergrift S \& Callaway R (1990) In situ Reclamation of Spills from Underground Storage Tanks: New Approaches for Site Characterization, Project Design, and Evaluation of Performance. Proceedings: Environmental Research Conference on Groundwater Quality and Waste Disposal. Washington D.C. May 2-4, 1989. Edited by I.P. Muraka, Electric Power Research Institute, Palo Alto, CA. and S. Cordle, U.S. Environmental Protection Agency. Washington DC (pp 30-1-30-16)

Zoetman BCJ, De Greef E \& Brikmann FJJ (1981) Persistency of Organic Chemicals in Groundwater, Lessons from Soil Pollution Incidents in the Netherlands. Sci. Tot. Environ. 21: 187-202 